\title{
ФРАКТАЛЬНИЙ АНАЛІЗ МРТ ЗОБРАЖЕНЬ МОЗКУ ЛЮДИНИ
}

\author{
Калашнікова Л.Є., доц. к.б.н. \\ doc_hom2000@yahoo.com \\ Бен Хмаед Сарі С.Салєм,студент \\ saribenhmaied@gmail.com \\ Факультет біомедичної інженерії \\ Національний технічний університет \\ «Київський політехнічний інститут імені Ігоря Сікорського» \\ м. Київ, Україна
}

\begin{abstract}
Реферат - Пухлина мозку є однією з найбільш поширених причин смертності людини. За даними Американської асоиіації пухлин головного мозку близько 80 тис. чоловіків, жінок і дітей мали діагноз первинної пухлини головного мозк протягом 2017 року. Рання діагностика раку шляхом скринінгу дозволяе сприяти зниженню смертності. Для иього може бути корисним фрактальний аналіз медичних зображень. У цій роботі досліджувались МРТ-зображення мозку здорової людини і мозку з різними типами пухлин. Фрактальна розмірність і показник Херста були обрані в якості діагностичних ознак томографічного зображення з використанням пакету програмного забезпечення Image J обробки FracLac зображень для фрактального аналізу з площею 640 x 480 пікселів. Розрахунки фрактальних розмірів зразків патологічних $i$ здорових тканин проводили методом короткого підрахунку. У патологічних випадках (пухлина головного мозку) показник Херста був менше 0.5 (зона нестабільних статистичних характеристик). Для здорової тканин індекс Херста більше 0.5 (зона стабільних характеристик). Дослідження показало можливість застосування фрактального швидкого аналізу для виявлення пухлин головного мозку людини. Експоненту Херста можна використовувати як важливу діагностичну характеристику для аналізу медичних зображень.
\end{abstract}

Ключові слова - МР-зображення головного мозку, пухлина головного мозку, фрактальні розміри, показник Херста, метод боксерного рахунку.

\section{I. ВСТУП}

Завдяки значній розповсюдженості та поганим довгостроковим результатам лікування, пухлина залишається однією 3 найважливіших проблем медицини. За даними Американської асоціації пухлин головного мозку близько 80 тис. чоловіків, жінок і дітей мали діагноз первинної пухлини головного мозку протягом 2017 року [17]. Очікується, що протягом наступних 20 років кількість нових випадків зросте приблизно на 70\%. Проблема поліпшення негайних i довгострокових результатів лікування знаходиться в найбільш тісному зв'язку 3 вирішенням питання раннього виявлення раку [15].

Наявність клінічних проявів при раку часто показує значну поширеність патологічного процесу.

Тому розширення діапазону діагностичних процедур під час безсимптомного раку представляється очевидним рішенням, насамперед завдяки поліпшенню форм скринінгу. Наприклад, у США розробка ранніх методів діагностики підвищила виживаність пацієнтів 31 у 69 до 1 у 22 випадках [2].
Діагностичні методи скринінгу з точки зору економії та безпеки можуть бути менш точними, ніж клінічний діагноз [18].

Автоматизована діагностика та аналіз зображень МР можуть бути одними 3 найбільш корисних методів скринінгу через їх здатність підвищувати ефективність обробки відносно великих обсягів інформації [16].

Сучасні дослідження показують, що багато природних об'єктів характеризуються фрактальною структурою, таку структуру мають бронхіальне дерево i артеріальне дерево [8]. Розробка технології фрактального аналізу перспективна для виявлення і опису будови пухлин головного мозку, зокрема, дозволяючи оцінити розвиток раку [9]. Однак лише в останні роки увага приділялася перевагам використання фрактальної геометрії в медицині, зокрема в кардіології та радіології. Кілька досліджень показали потенціал фрактального аналізу як морфологічної характеристики нерегулярних структур пухлин головного мозку, виходячи з того, що фрактальна геометрія $є$ теоретичною основою для вивчення та моделювання нерегулярних структур [12]. Наприклад, фрактальні 
характеристики використовувалися для представлення складних змін щільності і структури тканини молочної залози, які використовуються для виділення атипових областей на мамограмах [3].

\section{II.МЕТА ДОСЛІДЖЕННЯ}

Метою даного дослідження $є$ оцінка застосовності фрактального аналізу для виявлення пухлини головного мозку на МРТзображеннях. Як діагностичну ознаку томографічної візуалізації обрано фрактальну розмірність зображення та показник Херста. Фрактальна розмірність для регулярних фракталів описує повторюваність геометрії, а для нерегулярних описує повторюваність статистичних характеристик при масштабуванні [21].

\section{III. МАТЕРІАЛИ ДОСЛІДЖЕНЬ}

У дослідженні використовувався пакет програмного забезпечення Image J [19] для обробки зображень і спеціальне застосування FracLac [20] для фрактального аналізу. Цей пакет програмного забезпечення дозволяє аналізувати, редагувати, обробляти 8-, 16- і 32бітові зображення різних форматів включаючи формат DICOM, що особливо важливо в цій роботі, оскільки цей формат $€$ визнаним стандартом в радіологічних дослідженнях, зокрема, широко використовується для скринінгу.

Крім того, комплекс підтримує функції обробки зображень, такі як логічні та арифметичні операції над зображеннями, зміну контрасту i різкісті, згортку, згладжування, детектування країв, аналіз Фур'є. Зручно, що стало можливим в одній програмі здійснення процедур над зображеннями (виділення областей різних розмірів, зміна їх налаштувань і т.д.) i проведення фрактального аналізу.

Одним 3 найбільш широко використовуваних методів визначення фрактальної розмірності $\epsilon$ метод вікнапідрахунку. Його популярність пояснюється досить простими математичними розрахунками, емпіричною оцінкою та застосуванням тієї ж ефективності для точкових множин, лінійних об'єктів, областей та множин. У цьому методі область, що містить фрактал А, ділиться на квадратні клітини 3 розміром $\varepsilon$ на кожному кроці (на кожній стадії ітерації розмір $\varepsilon$ відрізняється від попереднього).

Потім для кожного випадку підраховується кількість клітин, необхідних для покриття області, що обробляється. Отримані значення представляються графіком $\ln N\left(\varepsilon_{i}\right)$, або експонентою Херста. 3 розміру осередку $\ln \varepsilon_{i}$, визначають тангенс кута нахилу лінії, який $\epsilon$ розміром клітини $D$. Розрахований розмір комірки $D \epsilon$ оцінкою фрактальної розмірності $D$.

$$
\ln \varepsilon_{i} \times D_{B}=\ln N\left(\varepsilon_{i}\right)
$$

Експонента Херста $€$ мірою самоподібності. Значення цього параметра для двовимірного сигналу (рис.1) визначається співвідношенням.

$$
D=2-H
$$

Чим ближче показник Херста до одиниці, тим більше виражені фрактальні властивості. Таким чином, значення показника Херста, що лежить в межах $0.7<H<0.9$ свідчить про самоподібний процес 3 довгостроковою залежністю. Такий процес $є$ нестійким (антиперсистентний), а при $H=0.5-$ випадковим процесом.

Ця робота була започаткована наступними кроками.

1) МРТ-зображення людського мозку в форматі * .dcm, що містить пухлину мозку, були відкриті в ImageJ.

2) За допомогою команди "Image-Crop" виділено область розміром 640 х 480 пікселів.

3) Застосування FracLac виконують розрахунки фрактальної розмірності $D_{B}$ для здорових і патологічних тканин методом Вохcounting. Показник Херста був розрахований за виразом (2).

4) Параметри WW (Window Width) i WL (Window Level) були скориговані для збільшення контрастності досліджуваних областей. Для вивчення зображень зі зміненими параметрами WW i WL у програмі RadiAnt DICOM Viewer були обрані правильні рівні контрастності для всієї серії досліджуваних томограм. Для існуючих досліджень діапазон WW і WL становить 614600 і 865-860 відповідно. Після цього у пакеті Image J були відкриті окремі розділи, де були задані необхідні параметри за допомогою команди Image - Adjust - Window / Level. 
Для отриманих значень середнє значення показника Херста і стандартного відхилення розраховувалися за формулами [21]:

$$
\begin{gathered}
\bar{\chi}=\frac{1}{n} \sum_{i=1}^{n} \chi_{i}(3) \\
\sigma=\sqrt{\frac{1}{n-1} \sum_{i=1}^{n}\left(\chi_{i}-\bar{\chi}\right)^{2}}
\end{gathered}
$$

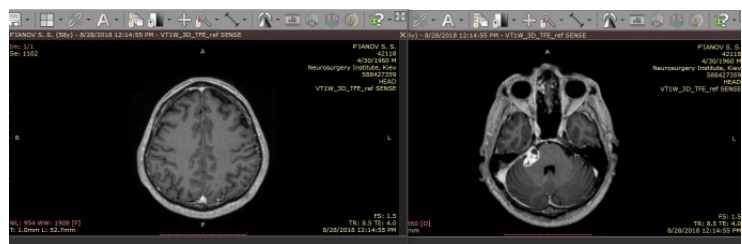

Рис. 1. Зображення зразків здорової мозкової тканини (на лівій картинці) та ) і мозкової тканини, що містить рак (на правій картинці)
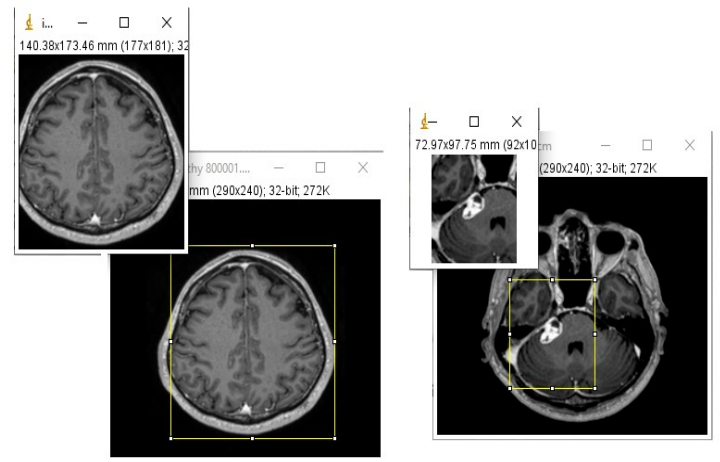

Рис. 2. Зображення зразків мозкової тканини (на лівій картинці) і мозкової тканини, що містить рак (на правій картинці) які скориговані за параметрами WW = $1860 \mathrm{i} \mathrm{WL}=1070$.

Щоб встановити оптимальний розмір досліджуваної області, зображення тканини мозку були проаналізовані в декількох зрізах 3 використанням кадрів різних розмірів.

Зрізи були також проаналізовані при оптимальних значеннях WW i WL, деякі приклади досліджуваних областей показані на рисунку 3 і рисунку 4.

\section{IV. РЕЗУЛЬТАТИ TА ОБГОВОРЕННЯ}

Результати показують, що у випадку патології показник становить менше 0,5 (область нестабільних статистичних характеристик), а для здорової тканини індекс Херста більше 0,5 (зона стабільних характеристик).

При обчисленні середнього та стандартного відхилення показника Херста для отриманих значень, було встановлено, що у випадку патології $H_{P}=0.278 \pm 0.06$, а у випадку здорової тканини $H_{N}=0.822 \pm 0.10$. Для отриманих результатів $D_{B}$ оптимальні значення для $\mathrm{WW}$ i WL $H_{P}=0.4024 \pm 0.05$, $H_{N}=0.822 \pm 0.10$.

Таблиця1. Отримані результати для розміру зображень 640x480 пікселів

\begin{tabular}{|c|c|c|c|c|}
\hline \multirow{2}{*}{$\mathrm{N}$} & \multicolumn{2}{|c|}{$\begin{array}{c}\text { Фрактальна розмірність } \\
\left(D_{B}\right)\end{array}$} & \multicolumn{2}{c|}{ ПоказникХерста $(H)$} \\
\hline & патологія & норм & патологія & норм \\
\hline 1 & 1,7026 & 1,3 & 0,2974 & 0.7 \\
\hline 2 & 1,6353 & 1,0 & 0,3647 & 1,0 \\
\hline 3 & 1,7992 & 1.2 & 0,2008 & 0.8 \\
\hline 4 & 1,7396 & 1,1 & 0,2604 & 0.9 \\
\hline 5 & 1,7574 & 1.2 & 0,2426 & 0.8 \\
\hline 6 & 1,6663 & 1,3 & 0,3337 & 0.7 \\
\hline 7 & 1,7792 & 1,1 & 0,2208 & 0.9 \\
\hline 8 & 1,6321 & 1,3 & 0,3679 & 0.7 \\
\hline 9 & 1,7879 & 1,1 & 0,2121 & 0.9 \\
\hline
\end{tabular}

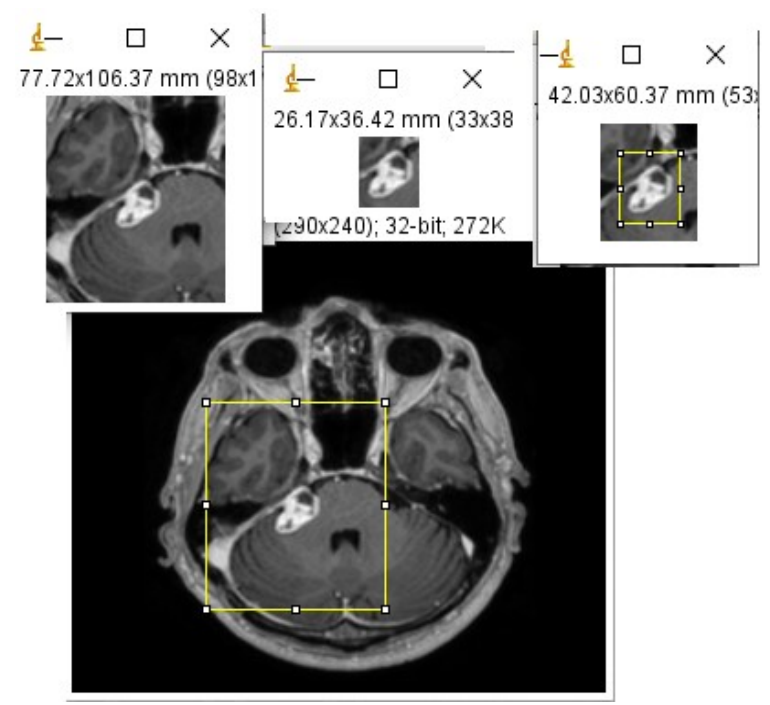

Рис. 3. Осередки, які вибрані для визначення оптимального розміру досліджуваної області

Таблиця 2. Отримані результати для зображень 3 оптимальними значеннямиWW і WL (614/865) 


\begin{tabular}{|c|c|c|c|c|}
\hline \multirow{2}{*}{$\mathrm{N}$} & \multicolumn{2}{|c|}{$\left(D_{B}\right)$} & \multicolumn{2}{c|}{ Практальна розмірність } \\
\hline & патологія & норм & патологія & норм \\
\hline 1 & 1,5 & 1,1 & 0,5 & 0.9 \\
\hline 2 & 1,6110 & 1,1 & 0,389 & 0.9 \\
\hline 3 & 1,6769 & 1,1 & 0,3231 & 0.9 \\
\hline 4 & 1,6847 & 1,1 & 0,3153 & 0.9 \\
\hline 5 & 1,6206 & 1.2 & 0,3794 & 0.8 \\
\hline 6 & 1,5857 & 1.2 & 0,4143 & 0.8 \\
\hline 7 & 1,5826 & 1.4 & 0,4174 & 0.6 \\
\hline 8 & 1,5851 & 1.2 & 0,4249 & 0.8 \\
\hline 9 & 1,5416 & 1.2 & 0,4584 & 0.8 \\
\hline
\end{tabular}

4. У зв'язку з тим, що при визначенні фрактальної розмірності методом боксерного рахунку використовується порогова обробка зображення, менш контрастна патологія не може бути врахована. Однак при виборі оптимальної контрастності тканини, якщо контрастна аномалія відрізняється від норми в будь-якому випадку, то дослідження повинно розглядатися медичним фахівцем.

У дослідженні розглянуто можливість створення фрактального експрес-аналізу на наявність пухлини головного мозку та рекомендації щодо його використання. Результати дослідження свідчать про значні

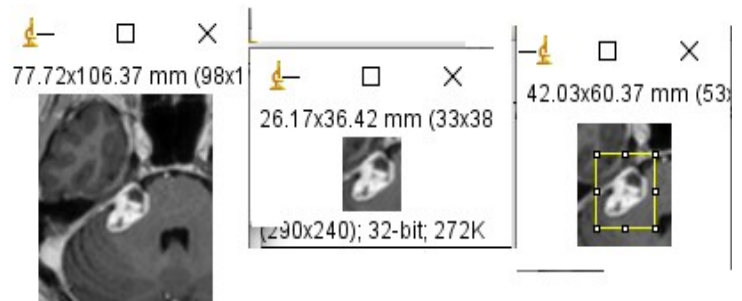

Рис. 4. Приклади. Розмір досліджуваних областей $77.7 \times 106.37$ пікселів

\section{V.ВИСНОВКИ}

На основі цих результатів можуть бути сформовані наступні рекомендації щодо використання фрактального аналізу для оцінки наявності освіти фокусів:

1. Вікно аналізу має бути досить великим. У цьому дослідженні найбільш прийнятні результати були отримані для розміру вікна 640 х 480 пікселів.

2. У вікні аналізу здорові тканини повинні займати більшу площу, ніж тканина, яка містить пухлина.

При аналізі здорові тканини повинні займати більший об'єм, ніж тканина, що містить пухлину. Це пов'язано 3 тим, що аномальна структура тканини також може бути достатньо однорідною, а ситуація 3 більшим обсягом однорідної патологічної тканини, ніж здорової, призводить до протилежного результату - здорові тканини сприймаються як аномальні, але результат аналізу має нормальний діапазон.

3. Краще, якщо томограма буде попередньо оброблена, тобто вибрані значення параметрів WW i WL такі, що буде істотна різниця в контрасті між патологічною i здоровою тканинами. У дослідженні значення знаходяться в межах WW 614 i WL-865. відмінності фрактальної розмірності і показника Херста між зонами здорової тканини мозку i ділянками, що містять пухлину.

Отже, показник Херста може бути використаний як важлива діагностична ознака. Отримані дані підтверджують, що для зображень патологічної тканини мозку людини показник Херста був менше 0.5, а для зображень здорової тканини показник Херста був більше 0.5 .

Це призводить до висновку щодо перспектив застосування фрактального аналізу для скринінгу медичних зображень. Головною перевагою фрактального аналізу $\epsilon$ можливість створити повністю автоматичний програмний метод системного відбору медичних зображень. Це дозволить заощадити час медичним працівникам, які оглядають знімки вручну, а також підвищити ефективність програм скринінгу, які можуть охоплювати велику кількість людей.

\section{ПЕРЕЛІК ПОСИЛАНЬ}

[1] Alharbi A, Tchier F, Rashidi M (2016). Using a genetic fuzzy algorithmas a computer aided breast cancer diagnostic tool. AsianPac J Cancer Prev, 17, 3651-8.

[2] Arteaga C, Adamson C, Engelman J, etal (2014). AACR cancer progress report 2014. Clin CancerRes, 20, 1-112.

[3] Caldwell C, Stapleton S, Holdsworth D, etal (1990). Characterisation of mammographic parenchymal pattern by fractal dimension. Phys Med Biol, 35, 235-47.

[4] Falconer K (2004). Fractal geometry: mathematical foundations and applications. John Wiley and Sons.

[5] Flegontov A, Marusina M (2009). The comparison method of physical quantity dimensionalities. InInternational Workshop on Computer Algebrain Scientific Computing, 81-8.

[6] Guo Q, Ruiz V, Shao J, Guo F (2005). A novel approach to mass abnormality detection in mammographic images. In Proceedings of the IASTED International Conference on Biomedical Engineerin . 180-5. 
[7] Hemsley A, Mukundan R (2009). Multifractal measures for tissue image classification and retrieval. In Proceedings of the 11th IEEE International Symposium on Multimedia, 618-23.

[8] Ishida T, Yamashita K, Takigawa A, Kariya K, Itoh H (1993). Trabecular pattern analysis using fractal dimension. Jpn J AppPhys, 32, 1867-71.

[9] Landini G, Rippin J (1993). Fractal dimensions of the epithelial-connective tissue inter faces in premalignantand malignant epithelial lesions of the floor of the mouth. Anal Quat Cytol Histol, 15, 144-9.

[10]Li J, Du Q, Sun C (2009). A nimproved box-counting method for image fractal dimensiones timation Pattern Recognit, 42, 2460-9.

[11]Lopez T, Manjarrez J, Plascencia N, etal (2009). Fractalanalysisof EEG signalin the brain of epileptic rats, with and without biocompatible implanted neuroreservoirs. Appl Mechand Mat, 15, 127-36.

[12] Mandelbrot B (1983). The fractal geometry of nature. Macmillan, 173, 250-65.

[13]Marusina M, Sizikov V, Volgareva A (2015). Noise suppression in the task of distinguishing the contours and seg mentation of tomographic images. J OptTechnol, 82, $673-7$.
[14]Mohammadzadeh Z, Safdari R, Ghazisaeidi M, Davoodi S, Azadmanjir Z (2015). Advances inoptimal detection of cancer by image processing; experience with lung and breast cancers. Asian Pac J CancerPrev, 16, 5613-8.

[15]Ng S, Wong S (2013). Colorectal cancers creeningin Asia. Br Med Bull, 105, 29-42.

[16]Podolsky M, Barchuk A, Kuznetcov V, etal (2016). Evaluation of machine learning algorithmutilization for lung cancer classification base dongeneex pressionlevels. AsianPac J CancerPrev, 17, 835-38.

[17] Stewart B, Wild C (2016). Worldcancerreport 2014. World

[18]Tsuda H, Moore M (2001). Cancerscreening: A review with particular attention to areas for future in ternational research efforts. Asian Pac J CancerPrev, 3, 99-123.

[19]Rasband W / National Institutes of Health / USA, [Electronicresourc], URL: https://imagej.nih.gov/ij).

[20]Karperien A / Charles Sturt University, Australia, [Electronicresourc] URL: https:// imagej.nih.gov/ij/plugins/fraclac/FLHelp/Introduction. htm).

[21]Alharbi A, Tchier F, Rashidi M / Using a genetic fuzzy algorithmas a computer aided breast cancer diagnostic tool / Asian Pac J CancerPrev, 2016 - p. 54.

\section{УДК 621.76.13.99}

\section{ФРАКТАЛЬНИЙ АНАЛИЗ МРТ ИЗОБРАЖЕНИЙ МОЗГА ЧЕЛОВЕКА}

Калашникова Л.Е., доц. к.б.н. dochom2000@yahoo.com

Бен Хмаед Сари С.Салем,студент saribenhmaied@gmail.com Факультет биомедицинской инженерии Национальный технический университет «Киевский политехнический институт имени Игоря Сикорского» м. Киев, Украина

\footnotetext{
Реферат - опухоль мозга является одной из наиболее распространенных причин смертности человека. По данным Американской ассоциации опухолей головного мозга около 80 тысс. мужчин, женщин и детей имели диагноз первичной опухоли головного мозга в течение 2017 года. Ранняя диагностика рака путем скрининга позволяет содействовать снижению смертности. Для этого может быть полезным фрактальный анализ медицинских изображений. В этой работе исследовались МРТ-изображения мозга здорового человека и мозга, содержащего различные типь опухоли. Фрактальная размерность и показатель Херста были выбраны в качестве диагностических признаков томографического изображения с использованием пакета программного обеспечения Iтаge J обработки FracLac изображений для фрактального анализа с площадью $640 x 480$ пикселей. Расчеты фрактальных размеров образиов патологических и здоровых тканей проводили методом короткого подсчета. В патологических случаях (опухоль головного мозга) показатель Херста был меньше 0.5 (область нестабильных статистических характеристик). Для здоровой ткани индекс Херста более 0.5 (зона стабильных характеристик). Исследование показало возможность применения фрактального быстрого анализа для выявления опухолей головного мозга человека. Экспоненту Херста можно использовать как важную диагностическую характеристику для анализа медицинских изображений.
}

Ключевые слова - МРТ-изображения головного мозга, опухоль головного мозга, фрактальные размеры, показатель Херста, метод боксерного счета. 


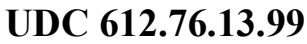 \\ FRACTAL ANALYSIS OF MRI IMAGE OF BRAIN OF HUMAN
}

\author{
Kalashnikova L.E., Assoc. Ph.D. \\ dochom2000@yahoo.com \\ Ben Hmaied Sari S.S., student \\ saribenhmaied@gmail.com \\ Faculty of Biomedical Engineering \\ National Technical University \\ " Igor Sikorsky Kyiv Polytechnic Institute "
}

Kiev, Ukraine

\begin{abstract}
Brain tumors are one of the most common causes of human mortality. According to the American Association of Brain Tumors, about 80,000 men, women, and children had a diagnosis of primary brain tumor in 2017. Early diagnosis of cancer by screening allows you to intervene to reduce mortality. For this purpose, a fractal analysis of medical images may be useful. In this study, we investigated the images of magnetic resonance (MR) of a healthy human brain and brain that contain different types of brain tumors. The fractal dimension and Hurst index were selected as diagnostic capabilities for a tomographic image using the Image $J$ software package for processing FracLac images for use in fractal analysis with an area of $640 \times 480$ pixels. Calculations of fractal sizes of samples of pathological and healthy tissues were performed by a short counting method. In pathological cases (brain tumor), the Hurst score was less than 0.5 (the region of unstable statistical characteristics). For healthy tissue, the Hurst index is more than 0.5 (zone of stable characteristics). The study showed the possibility of using a fractal rapid assay to detect brain tumors of a person. The Hurst Exhibitor can be used as an important diagnostic characteristic for the analysis of medical images.
\end{abstract}

Key words - MRI brain image, brain tumor, fractal dimensions, Hurst index, method of boxing account. 